\title{
The Basic of Self-Management in Asian Folklore
}

\section{Noraini Binti Zainal Abidin and Nik Rafidah Nik Muhamad Affendi}

To Link this Article: http://dx.doi.org/10.6007/IJARBSS/v11-i2/8100

DOI:10.6007/IJARBSS/v11-i2/8100

Received: 19 December 2020, Revised: 15 January 2021, Accepted: 24 January 2021

Published Online: 09 Febuary 2021

In-Text Citation: (Abidin \& Affendi, 2021)

To Cite this Article: Abidin, N. B. Z., and Affendi, N. R. N. M. (2021). The Basic of Self-Management in Asian Folklore. International Journal of Academic Research in Business and Social Sciences, 11(2), 132-140.

Copyright: (c) 2021 The Author(s)

Published by Human Resource Management Academic Research Society (www.hrmars.com) This article is published under the Creative Commons Attribution (CC BY 4.0) license. Anyone may reproduce, distribute, translate and create derivative works of this article (for both commercial and non-commercial purposes), subject to full attribution to the original publication and authors. The full terms of this license may be seen at: http://creativecommons.org/licences/by/4.0/legalcode

Vol. 11, No. 2, 2021, Pg. 132 - 140

Full Terms \& Conditions of access and use can be found at http://hrmars.com/index.php/pages/detail/publication-ethics 


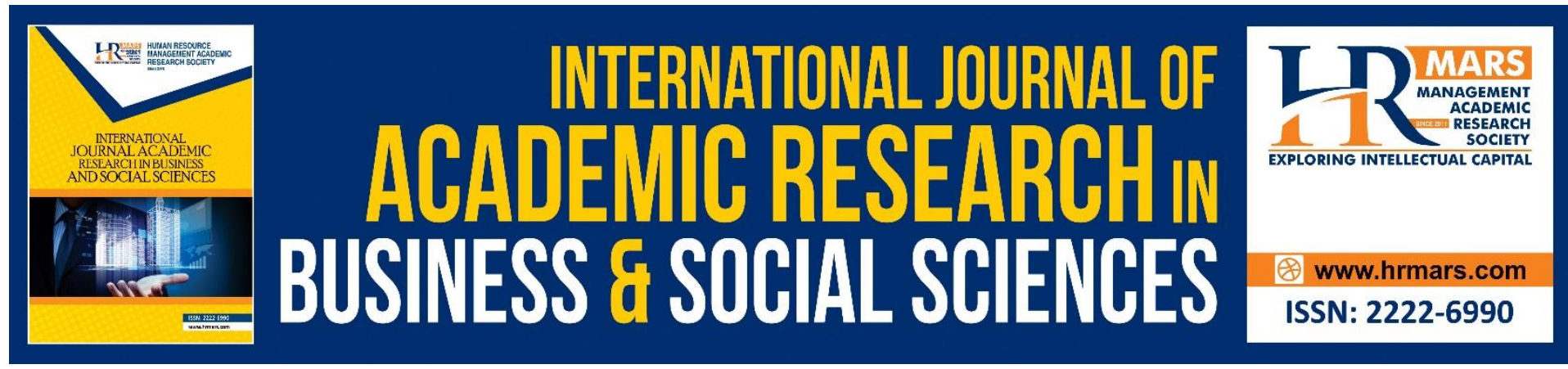

\title{
The Basic of Self-Management in Asian Folklore
}

\author{
Noraini Binti Zainal Abidin and Nik Rafidah Nik Muhamad \\ Affendi \\ Faculty of Modern Languages and Communication \\ Universiti Putra Malaysia, 43400 Serdang, Selangor, Malaysia
}

\begin{abstract}
Without management, human lives will face with a lot of risk. For example, self-management has become a basic thing that has been exposed since childhood by adults as well as individuals nearby. Such exposure is also applied in children's books from an early age as a useful initial input. In this case, the management aspect is knowledge-based that has been widely introduced in Asia for a long time. This can be seen in the Koleksi Cerita Rakyat Asia Untuk Kanak-kanak (Buku 1) which has been published by the Dewan Bahasa dan Pustaka as a result of the Asian Copublication Programme, organized by the Asian Cultural Centre for Unesco / Tokyo Book Development Centre, in collaboration with Unesco and the countries of UNESCO members in Asia. The findings also showed that the dominant basis of selfmanagement which covers basic things such as time management, emotions, conflict and hygiene.
\end{abstract}

Keyword: Management Basics, Self, Folklore, Children, literature, Asian

\section{Introduction}

This life requires every human being to be independent in managing themselves in order to make a living. Generally, normal human beings are able to manage themselves in their daily lives. This is because, self-management has been exposed since childhood as the basis of human needs. In fact, good self-management contributes positive effects to one's daily life. Robiah (2001), stated that a good self-management in terms of physical aspects, will make it easier for you to be accepted by all members of society everywhere. Without good selfmanagement, a person not only faces various risks, but also burdens the people around him or her. In this case, self-management is a basic thing that is practiced before he or she manages others. Additionally, the aspect of self-management in living this life is more synonymous with adults compared to children. According to Norsaliza, Rosli and Azhar (2017), children cannot live alone without being guided. This is because children are people who are just beginning to get to know the world without any knowledge. In this context, children's reading materials are a channel or medium of education for children to get initial input, especially self-management as a basis in living life. For example, the information found in reading materials such as folklore can provide initial input to children in managing things. According to Misran (2005), the philosophy behind folklore is the beginning of the learning process to children by learning how to handle something or a situation. This exposure is important for children's knowledge in their daily lives. Although originally folk tales were 
presented to the public regardless of age, but the passage of time has caused the genre of folk tales to get the attention from children. According to Hadijah (2006), folklore is not only the most widely published, but also the earliest children's literary genre to be recorded. In this case, folklore has been re-edited again according to the age of the child. However, the passage of time has caused the genre of folklore to be considered as a reading material that applies the element of entertainment only and does not contribute any benefits to the reader. This statement is in line with Noriah (2016), who stated that the unfortunate fates of folklore has been disputed for its suitability as content that can shapes one's personality. While the content behind folklore can display the learning process on how to manage things and situations. Thus, the objective of this study is to classify the basics of self-management in Asian children's folklore and analyse the basics of self-management in children's folklore. This study also examines the book "Asian People For Children" (Book 1) Collection which has been printed repeatedly four times. This collection of stories is once again being researched upon when the question arises that folk tales for children today are disputed as reading material that provides basic input to children for carry out their lives even though the countries in Asia have produced 6 collections of folk tales for children starting from 1975. Thus, the collection that was used has 7 stories, but only a few stories were scrutinized for this study, "Burung Gagak dengan Burung Ciak" from Bangladesh, "Cerita Sirih dengan Pinang" from Vietnam, "Sahabat dengan Seteru" from Iran and "Orang Muda dengan Harimau" from Korea.

\section{Research Objectives}

- To classify the basics of self-management in Asian children's folklore.

- To analyze the basics of self-management in Asian children's folklore as a basis for children to carry on with their lives.

\section{Review of Past Studies}

Research on children's folklore in the context of management has been carried out by previous researchers. A study conducted by Rafidah (2016) entitled "Pengurusan Konflik dalam Cerita Rakyat Nusantara Abad ke 19" showed a society that indirectly practiced the technique of dealing with conflict to live a daily life. From that, the management element is introduced to children through the teaching values contained in reading materials. Futhermore, there is also a study entitled "Fenomena Sosial dalam Cerita Rakyat Kanakkanak" by Arba'ie, Liliy and Rafidah (2011). The results of the study showed the relevance of social phenomena in society in managing their daily lives. In this case, the discussion of this study has touched on the management elements indirectly from the point of view of traditional community leadership system, the government system and human values as important guides and guidelines to children in going through life. In addition, there are also studies that touched on management elements through children's local animated stories. Norsaliza, Rosli and Azhar (2017) entitled "Keupayaan Pengurusan Intektualisme Kanakkanak dalam Kekuasaan Animasi Upin dan Ipin". The focus of this study discussion proved that the influence of animation as a new innovation in shaping and developing children's thinking. Indirectly, management elements are highlighted through aspects of leadership applied in animation to encourage children to manage their intellectualism in their daily life. There is also another study that displayed management elements in the context of children by Rafidah, Azman and Normaliza (2019). The results of the study showed that the message conveyed to children acts to stimulate the mind in overcoming and solving problems. 
Indirectly, aspects of management are applied in children's reading materials through characters and storytelling plots.

\section{Research Methodology}

This discussion used two methods, the library method and the text analysis method. For text analysis methods, management approach was used to examine the appropriate study materials in a more relevant way. The management approach has been introduced by Mohamad Mokhtar to examine literary works in the context of management. Through this approach, the study of management in literary works can be discussed in detail. According to Mokhtar (2016), management approach in literary criticism is based on the study of management that its key is the process of achieving the goals and targets of an organization. However, this discussion only limits by applying three of the five principles, the principles of planning, control and leadership. The principles used can prove the basics of management that were introduced are one of the strengths in children's reading materials. In addition, the study materials in this discussion are reading materials that received the response of the audience until it was reprinted four times by Dewan Bahasa dan Pustaka. The collection entitled "Cerita Rakyat Asia untuk Kanak-kanak" (Buku 1) is the result of the Asian Copublication Program, organized by the Asian Cultural Center for Unesco / Tokyo Book Development Center in collaboration with Unesco and the countries of UNESCO members in Asia. However, this discussion only focused on the basics of self-management contained in 4 stories, namely, "Burung Gagak dengan Burung Ciak" from Bangladesh, "Cerita Sirih dengan Pinang" from Vietnam, "Sahabat dengan Seteru" from Iran and "Orang Muda dengan Harimau" from Korea. Therefore, this discussion will examine Asian folk tales for children in the basic context of self-management.

\section{Discussion and Findings}

Each individual has their own way and style in managing themselves. For example, an individual's self-management is formed from their background, environment and society. In fact, a positive environment also plays a role in influencing a person in managing daily activities. For children, exposure to self-management can be obtained from the closest people such as parents and family members. In this context, self-management by parents and family members is the closest example in the world of children. However, children's reading materials, especially folklore, display guides and guidelines through messages and moral values. Therefore, the results of data collection displayed aspects of self-management such as cleanliness, time, emotions and conflict are the dominant management basics in the study materials.

\section{Self-management through the aspect of hygiene}

Every human being is responsible in managing themselves especially the aspect of personal hygiene. Such responsibilities can develop an independent attitude and not continue to depend on others. According to Ahmad and Zahroh (2016), clean culture is a reflection of society's attitude and behaviour in taking care and maintaining personal hygiene and the environment in daily life.

In this context, the basics of personal hygiene can be examined through the hygiene of the body as well as clothing. This is one of the aspects of self-management that is so important to health and appearance. In fact, the aspect of hygiene can also influence a person in living life. For children, the basics of personal hygiene can be obtained from their home and 
environment. Thus, the aspect of personal hygiene is important for children to have healthy and comfortable living habits. Here is an example of an excerpt in the story "Burung Gagak dengan Burung Ciak" from Bangladesh which displayed lessons for neglecting the aspect of personal hygiene:

"All right," said the Sparrow, "I will keep my promise. But, before you eat me, you must first wash your beak. Everyone knows you are a filthy beast: you eat a lot of dirty things." So, the crow went to the river and shouted: "River! River! Give me water, I must wash my beak, To be clean, I can eat the chirping bird!" The river answered, "Do you want water? Alright, but everyone says you like to eat dirty things. If you want to wash your beak first with my water, you must find a pot to fill it with water".

(Burung Gagak dengan Burung Ciak:2)

The passage above described the aspect of cleanliness that is not well managed by the Crow. The failure of the Crow character to manage the aspect of personal hygiene causes his friends and acquaintances to always be careful when dealing with him. Through the principles of planning, Sparrow character has devised a strategy to save himself. First, the Sparrow questions the aspect of cleanliness in the character of the Crow. After that, the Sparrow performs a trick by asking the character Crow to clean himself first before he can eat it. Although it is a trick, but the neglect of hygiene aspects by the character of Crow caused him to continue to be avoided by the River, Buyers, Land, Blacksmiths and Farmers. Finally, the Sparrow managed to save himself from the threat of the Crow who fails to clean himself. In addition, it is clear that the aspect of personal hygiene is important in living a comfortable life. The ability to manage aspects of personal hygiene can clearly provide benefits as shown in the Asian children's stories. Therefore, children's folklore also displayed the effects of neglecting the aspect of personal hygiene. This exposure is important in shaping children's discipline of self-responsibility in managing aspects of hygiene to ensure personal health.

\section{Self-management through the aspect of time}

Time management is an important aspect in daily life. In this case, effective time management showed that an individual is able to carry out goals he or she set. The effectiveness of managing time also has certain methods or ways so that they are not a waste. For children, they have more free time and time to play, do sports and live life without thinking about burdensome work. According to Farra (2018), children generally do not have a proper time management or daily schedule. However, after entering school, children are exposed to aspects of time management in living daily life more effectively. Such exposure can discipline children to use time effectively. This is in line with the opinion of Nadhirah \& Noraini (2014), who stated that this childhood education can indirectly form the discipline and commitment of children to be punctual and use it as best as possible.

Thus, the ability to manage time since childhood makes a person more focused and responsible. The following is an example of an excerpt from the story "Orang Muda dengan Harimau" from Korea that showed the aspects of time management effectively by implementing a set planning strategy:

The young man called his friends and told them what to do. The beetle was told to wait in the room to extinguish the candle when the tiger entered. He told the eggs to hide in the embers to break and blow the tiger's eyes when it was close. He told the crabs to hide in the basin so that they could scratch the tiger's eyes. 
Then the young man placed the needle under the floor by the door. He told the mortar to climb on the roof and the wooden barrel he told to hide in the store. He told them to take the tiger away when they are told later.

(Orang Muda dengan Harimau:31)

The display of events showed the ability to manage time well by the character of Young man. According to Brooks and Terry (1997), starting a day without a plan, will certainly waste valuable time. In this case, the character of the Young man does not waste time and continues to devise strategies to help the girl kill the Tiger. Through the planning strategy, the Young man can achieve the objectives that are set. Maimunah (2000), plans to use time effectively which will eventually lead to a set goal line. The first step that was taken by the Young man is to formulate a strategy that is carried out to defeat the opponent. Once the strategy is set, the Young man distributed the task to his friends to collaborate. Furthermore, the Young man also chose the right time to act in achieving objectives. Additionally, the ability to manage time well can provide successful results as stated. Therefore, children's folklore also revealed the importance of effective use of time, especially to individuals and organizations. Such exposure clearly showed the aspects of time and planning are interrelated to achieve a goal or task. With that, the ability to manage time is very important for children in shaping their self-discipline.

\section{Self-management through the aspects of emotion}

Self-management not only involves external aspects, but also involves internal aspects such as emotions. Robiah (2001), stated that the first step in building a personal is to learn to control oneself in terms of emotions and thoughts. Although emotion is one of the uniqueness of every human being, but human beings need to control it so as not to affect themselves and the environment. According to Mok (2010), emotions are naturally reflective responses that have been linked in the nervous system in the human brain as a mechanism to communicate the individual's feelings. In this case, emotions served as a human channel to express feelings through words or actions. However, the diversity of emotions has caused humans to have their own way of living this life. Therefore, emotions need to be handled well from the beginning, especially children so as not to cause any problems to themselves and the environment. Children clearly need exposure to abilities and emotional control in their developmental process when they grow up Amin (2003). This can be detected in the story "Cerita Sirih dengan Pinang" (2018) which displayed self-management from an emotional aspect:

Cao Lang felt empty and his heart was very sad. But, because of his deep love for his brother, he did not say anything. Xuan Phu agrees to marry Cao Tan when Cao Tan comes to his house together to propose. Xuan Phu thinks Cao Tan is Cao Lang, because he has never talked to Cao Lang and the two siblings are similar. With that, Cao Tan and Xuan Phu were married. Cao Lang held back his sadness as much as he could. Xuan, on the other hand, when he found out about his mistake, accepted the fate that befell him with a willing heart.

(Cerita Sirih dengan Pinang:40)

The above passage described the ability to deal with negative emotions to form a positive attitude in oneself. According to Azhar (2006), people who have high emotional management are able to have a strong spirit of strength, perseverance, courage, invincibility, confidence, 
independence and always positive thinking. For example, sad emotions are negative emotions that affect oneself if not addressed. In this case, the character of Cao Lang tried to deal with sad emotions so as not to break his spirit to live daily life as usual. Through the principle of control, the character of Cao Lang showed the methods used to deal with emotions within himself so as not to stray from his objectives. One of the control methods done by the character of Cao Lang is to correct his spirit so as not to affect the goals set. That spirit is an act of control that gives direction to his achievement. According to Mok (2010), if viewed from a positive angle, the task of grief moves a person who is involved to try to escape from grief. In this case, sadness becomes an encouragement and boosts the spirit to a person to improve themselves and life to be better. Although the character of Cao Lang was sad about the marriage of his brother and Xuan Phu, but because of family matters, the character of Cao Lang dealt with those sad emotions. Cao Lang's character's ability to curb negative emotions from continuing can be overcome when Cao Lang's character tried not to damage family relationships by allowing his brother to marry the woman of his choice. This has a positive impact on the achievement of Cao Lang's character's goal to continue living a happy life. Therefore, control actions should be implemented when faced with emotions that can jeopardize objective decisions. The depiction of such events is important for shaping positive behaviors through emotional intelligence. Thus, the folklore of Asian children also displayed the influence of good emotional control over indirect behavior.

\section{Self-management through conflict}

The ability to deal with conflict is also important for every individual in daily life. In this context, conflict management skills must be present in each individual so as not to face stress. In fact, the ability to deal with a conflict clearly displays the attitude of leadership within oneself when faced with difficult situations. According to Foad (2005), the process of conflict management is problem solving or decision making that is, the level we try to handle and then deal with the conflict. Actions and choices when faced with conflict clearly prove an individual's ability to solve problems. In this case, conflict management is very important in human life whether they are adults or children. According to Siti \& Rafidah (2014), exposure on how to deal with crisis in life and how to solve it can shape the physical and mental maturity of children. Through such exposure, children can solve a problem more maturely. Therefore, the ability to deal with a conflict can also form a leadership attitude in a person. Hence, the ability to deal with conflict is important for each individual to be able to act more maturely and calmly as in the following passage:

He also said to Seteru, "We have agreed to share food. You have eaten what I have, but now you do not want to share your rights with me. " "I am a wise man," replied Seteru. "Our journey may be long. If I share my supplies with you, it will run out soon. We will be equally hungry. If I keep the supply to myself, I will be safe. "If that is your attitude," said Sahabat, "We do not have to travel together again," When arrived at the one intersection in front of them, they parted ways.

(Sahabat dengan Seteru:15)

The passage above described events related to self-management when faced with a conflict. The ability to deal with a conflict whether it is large or small can be examined in the character of a Sahabat. Through the principles of leadership, Sahabat was able to deal with conflicts that occur. Although in the beginning the character of Sahabat was deceived by the character of Seteru, but the character of Sahabat managed to get through his adventure well. According to Foad (2005), the conflict management process is problem solving or decision making, which 
is the level we try to handle and then deal with the conflict. In this case, the leadership within the character of Sahabat is not easily discouraged and determined to succeed. The character of Sahabat acted to continue the journey despite being disappointed by the actions of the character of Seteru. In fact, the courage in the character of Sahabat can be examined through his actions to try to treat the princess who is sick. Although the secret to treating the princess is unsure of its authenticity, but the character of Sahabat is still brave in continuing his plans. With that courage, the character of the Seteru has succeeded in instilling the trust of the character of the King. Finally, the character of Sahabat managed to heal the princess and would become the leader in the state. In addition, the ability to deal with a conflict can display leadership in a person before leading a group or organization. Therefore, the folklore of Asian children also showed the importance of dealing with a conflict. The ability of individuals to deal with a conflict is important to form self-confidence and courage when faced with difficult situations.

\section{Conclusion}

In conclusion, the discussion showed that the folklore of Asian children has featured elements of self-management related to various aspects such as cleanliness, emotions, time and conflict. In this context, guidance and knowledge in self-control, activities, time and many more can be introduced as preparation for children to manage and control their daily life. Additionally, the folk tales of Asian children clearly displayed content that fits the needs of children to live a daily life. Indirectly, children are able to recognize the processes of handling a thing or situation. Such exposure is also an alternative to educating children through informal education. With that, it is important for management studies to be practiced at the beginning of child development as what has been highlighted for so long in the folklore of Asian children since the old days.

Therefore, the contribution from this study is especially to the next researchers in examining the genre of folklore through various disciplines of knowledge for children. The use of new disciplines on knowledge in this research can also expand the world of children's literature in improving its quality as the main reading materials for children. This research proved that the management approach is not only focused on the study of adult works but also applied in the context of children. Such exposure also displays the management aspect as a basis in human life without favoring adults or children. Indirectly, children's literature displays their own abilities and capabilities as a channel for educating children. In fact, the management approach showed that the folklore of Asian children today still applies the principles of selfmanagement even though it is still not thorough.

\section{References}

Ahmad, Z., \& Zahroh, S. (2016). Perilaku Kebersihan Diri (Personal Hygiene) Santri di Pondok Pesantren Wilayah Kabupaten Brebes akan Terwujud Jika Didukung dengan Ketersediaan Sarana Prasarana. Jurnal Promosi Kesehatan Indonesia, 11(2), 64-83.

Arba'ie, S., Liliy, S. R., \& Rafidah, N. (2011). Fenomena Sosial dalam Cerita Rakyat KanakKanak. Pendeta Journal of Malay Language, Education and Literature, 2(1), 138-151.

Farra, H. (2018). Pemikiran dalam Cerpen Kanak-kanak Pilihan dari Tahun 2012 hingga 2015. (PhD Tesis). Universiti Putra Malaysia.

Hadijah, R. (2006). Peranan dan Perkembangan Sastera Kanak-kanak. Kuala Lumpur: Dewan Bahasa dan Pustaka. 
Maimunah, O. (2000). Perangkap Masa Panduan Pengurusan Masa Berkesan. Kuala Lumpur: Institut Tadbiran Awam Negara, Jabatan Perkhidmatan Awam.

Misran, R. (2005). Pendidikan Moral Menerusi Bahan Sastera Kanak-kanak. Dewan Sastera, 35, 31-44.

Mokhtar, M. A. H. (2016). Pendekatan Pengurusan dalam Kritikan Kesusasteraan: Syarahan Perdana. Kuala Lumpur: Universiti Malaya.

Amin, M. (2003). Perkembangan Kanak-kanak. Kuala Lumpur: Dewan Bahasa dan Pustaka.

Azhar, M. (2006). EQ Panduan Meningkatkan Kecerdasan Emosi. Kuala Lumpur: PTS Professional Publishing Sdn. Bhd.

Foad, M. S. (2005). Pengurusan Konflik. Kuala Lumpur: Dewan Bahasa dan Pustaka.

Mok, S. S. (2010). Kompetensi Kecerdasan Emosi. Selangor: Penerbitan Mulitimedia Sdn. Bhd. Nadhirah, A., \& Noraini, S. (2014, May 26-27). Persepsi Mahasiswa Kolej Universiti Islam Antarabangsa Selangor (KUIS) terhadap Amalan Pengurusan Masa. E-proceedings of the Conference on Management and Muamalah (CoMM): Synergizing Knowledge on Management and Muamalah, Kolej Universiti Islam Antarabangsa Selangor (KUIS). http://conference.kuis.edu.my/comm2014/eproceedings/C035\%20PERSEPSI\%20MA HASISWA\%20KUIS\%20TERHADAP\%20AMALAN\%20PENGURUSAN\%20MASA.pdf

Rafidah, N., Azman, A., \& Normaliza, A. B. (2019). The Funtions of University of Leiden's Malay Language Reading Material Among Malaysian Children. Asian Social Science, 15(4), 8593.

Rafidah, N. (2016). Pengurusan Konflik dalam Cerita Rakyat Nusantara Abad ke-19. Jurnal Antarabangsa Alam dan Tamadun Melayu (Iman), 4 (2), 37-43.

Noriah, M. (2016). Cerita Rakyat Melayu: Nasib yang Malang. Dewan Sastera, 46, 42-44.

Norsaliza, R. S., \& Azhar, W. (2017). Keupayaan Pengurusan Intelektualisme Kanak-kanak dalam Kekuasaan Animasi Upin dan Ipin. Jurnal Peradaban Melayu, 12, 71-87.

Robiah, K. H. (2001). Teknik dan Strategi Membimbing Remaja: Pengurusan Diri. Pahang: PTS Publications \& Distributors Sdn. Bhd.

Siti, Z., \& Rafidah, N. (2014). Konflik dalam Cerita Rakyat dan Kesannya kepada Kanak- kanak. Pendeta Journal of Malay Language, Education and Literature, 5(1), 189-205.

Brooks, W. T., \& Mullins, T. W. (1997). Pengurusan Masa Berkesan Hebat. Kuala Lumpur: Dewan Bahasa dan Pustaka. 